\title{
Larval Biology of Black Cutworm Agrotis ipsilon on Maize in Kashmir
}

\author{
Aoufa Mushtaq ${ }^{1 *}$, Z. H. Khan², S. S. Pathania ${ }^{2}$, Sajjad Hussain Mir ${ }^{1}$, \\ Khalid Rasool $^{3}$, Showkat Maqbool ${ }^{4}$ and Raihana Habib Kant ${ }^{5}$
}

\author{
${ }^{1}$ Division of Entomology, ${ }^{3}$ Division of Horticulture, ${ }^{4}$ Division of Agri. Statistics, ${ }^{5}$ Division of \\ Agronomy, Faculty of Agriculture, Wadura, SKUAST-K, India \\ ${ }^{2}$ Division of Entomology, Faculty of Horticulture, Shalimar, SKUAST-K, India
}

*Corresponding author

\section{A B S T R A C T}

\section{Keywords}

Agrotis ipsilon,

Larval instar, Head width, Mortality

Article Info

\section{Accepted:}

26 January 2021

Available Online:

10 February 2021
The present investigation was carried during year 2019-2020 at Division of Entomology, Faculty of Agriculture, Wadura, Sopore. A total of six larval instars of Agrotis ipsilon, were noticed in three generations of one calendar year, during the present study. The average length and breadth from first to sixth cutworm caterpillars ranged between 1.88 $34.21 \mathrm{~mm}$ and $0.35-3.5 \mathrm{~mm}$ respectively. Whereas, the mean developmental duration of the various larval instars ranged from 6.93-11.88 days, 4.60-9.38 days and 5.85-10.45 days for first, second and third generation respectively. The mean larval head width gradually increases in the successive instars, The mean larval head width ranges from 0.30 $3.00 \mathrm{~mm}, 0.30-3.36 \mathrm{~mm}$ and $0.30-3.28 \mathrm{~mm}$ for first to sixth instar in first, second and third generation. Study of larval mortality revealed that the maximum cumulative death percentage was in forth larval instar as 35.67 per cent, while as the minimum larval mortality was computed for first larval instar as 11.00 per cent.

\section{Introduction}

In Kashmir valley, Agrotis ipsilon is a destructive pest on maize, potato, vegetable crops, flowers and fruit seedlings, reducing the plant stand and biological yields (Reshi, 1967). The extent of damage due to black cutworm in maize is $30-40$ percent and 90 percent under moderately and heavily infested conditions respectively. The damage inflicted to maize seedlings is mainly from April to third week of June when saplings are two to six leaf stages and May sown crop is most severely damaged (Lone and Zaki, 1999).
This period coincides with sowing and transplanting of most of the crops. The larvae of Agrotis ipsilon are popularly known as greasy cutworm or black cutworm in Asia and North America. Black cutworm is a cosmopolitan pest known to attack at least 49 species of cultivated plants besides feeding on many weed species (Odiyo, 1975). The nocturnal larvae of this pest cut the haulms and stalks of young plants at the collar region and defoliate the plants in their early growth stage (Rajendra and Verma, 1989). They rarely consume the entire plant, but more commonly move to the next plant and damage 
in the row or to another row. Larvae spoil more than they consume and a severely infested field looks like as if it has been grazed (Johnson and Lewis, 1982 and Showers, 1997). The damage often goes unnoticed until after a significant number of plants have been damaged. Maximum yield losses are reported in com when $4^{\text {th }}$ to $6^{\text {th }}$ instar larvae feed on plants at coleoptile to four leaf stage (Showers et al., 1983). Later stages of cutworm cut entirely through the plants or tunnel into the plants below or above the soil surface, whereas small stage cutworms climb plants and chew small holes in the leaves. Gholson and Showers (1979) indicated that a negative photo taxis is the primary factor governing nocturnal behavior of black cutworm larvae. Early instar larvae are photopositive, whereas later instars are photonegative. To overcome the yield losses and for evolving suitable management strategies, knowledge of life cycle of the pest and its behavior is essential so as to know the most vulnerable stage of the pest. The biology of the pest, number of generations passed and the time taken vary in different agro climatic regions of the world. It is widely accepted that larval survival is greatly determined by the oviposition behavior of adult females, as immature stages have limited mobility (Renwick, 1989) Multiple sets of life table data can be analyzed to identify key mortality factors or critical life stages or periods, which can increase understanding of the dynamics of an insect population and at the same time, reveal the most appropriate period for management (Harcourt, 1969; Southwood, 1978a). Therefore, a regional approach for studying its biology is useful in evoking effective management system for the pest.

\section{Materials and Methods}

The biological studies of Cutworm spp. were done in the Experimental laboratory, Division of Entomology SKUAST-K, Shalimar; the initial culture of the pest was maintained by field collection. Neonate larvae of different species collected from different location on solanaceous vegetable/maize crops was held in plastic containers $(5.5 \times 7 \mathrm{~cm})$ having leaves of respective crops. To keep the leaves fresh for longer duration, wet cotton will be placed around the leaf petioles. The early instars larvae was reared in same rearing chamber, while later instars will be segregated and reared separately/ individually to avoid cannibalism. The food was changed daily till the larvae pupate.

\section{Observations to be recorded at larval stage}

The observations were recorded on ten newly emerged larvae (0-20 hour's age) from egg and rearing them up to pupal stage. The observations to be recorded were:

Growth and duration of curvature

Mortality

Head width

Size (morphometrix)

Change in colour

The length and breadth of the instars larvae was to be measured with the help of digital vernier caliper and graduated scale. The daily observations were recorded in respect of molting, change in colour, size and head width under a microscope for first and second instars and by naked eye for the rest of instars. The listed observations were repeated for all the generations of cutworm spp. To get accurate measurements of larval instars and head width, these stages were preserved in KAAD solution [Kerosene oil (1 part): absolute alcohol (10 parts): glacial acetic acid (2 parts) and dioxane (1 part)].

\section{Results and Discussion}

Ten newly hatched (0-12 hours) individuals of larvae from each generation were studied. 
Observation with regard to change in colour, length (with help of vernier caliper), head width and moulting showed that larvae passed six instars before changing into pupa. They curve compactly (C- shaped) on being disturbed. The head was dark brown in colour possessing a hard sclerotised capsule. Pair of jointed legs and spiracles on pleural side of each thoracic segment were present. The ventral side of larva was light in colour as compared to that of dorsal side. Abdomen was ten segmented with small setae irregularly sparsed all over the body, and concentrating in the last abdominal segment. Abdominal pro-legs were also present on third, fourth, fifth, sixth and tenth segment respectively. The duration of various larval instars, head width were found to vary from generation to generation and is precisely tabulated and presented in below.

The first (I) instar larvae were grayish in colour with a shining black head. The newly hatched larvae moved like a semilooper and fed on leaf petioles present in the jar. The average length and breadth of I-instar larvae was ranged between 1.8-2.3 mm with mean of $1.88 \pm 0.11$ and $0.35-0.52 \mathrm{~mm}$ with the mean of $0.42 \pm 0.10$ respectively. The width of head capsule ranged from 0.30-0.34 mm $(0.32 \pm 0.03) ; 0.27-0.34 \mathrm{~mm}(0.3+0.05)$ and $0.30-0.36 \mathrm{~mm}(0.31 \pm 0.03)$ for first, second and third generation respectively, and the instar lasted for 6-8 days $(6.93 \pm 0.22)$; 4-6 days $(4.60 \pm 0.32)$ and $5-7$ days $(5.85 \pm 0.29)$ days, during first, second and third generation respectively.

The second (II) instar larvae on moulting possesses translucent head capsule which later changes to brown and finally black in colour. The length and breadth of second instar varied between 3.1- $4.6 \mathrm{~mm}(3.51 \pm 0.27)$ and 0.60 $0.83 \mathrm{~mm}(0.81 \pm 0.04)$, respectively (Table 1). However, the head width of second instar for first, second and third generation ranged from
$0.45-0.52 \mathrm{~mm}(0.50 \pm 0.04) ; 0.44-0.49 \mathrm{~mm}$ $(0.48 \pm 0.03)$ and $0.42-0.47 \mathrm{~mm}(0.46 \pm 0.02)$ respectively (Table 2 ). Similarly the duration for development shows differences among the three generations of second instar larva which was 5-7 days $(5.88 \pm 0.28)$; $3-4$ days $(3.23 \pm$ $0.18)$ and $5-5$ days $(4.18 \pm 0.36)$ respectively (Table 2).

Studies on third (III) larval instar revealed that its length was recorded to vary from 5.5$7.2 \mathrm{~mm}(5.99+0.21)$ and breadth ranged from and $0.91-1.3 \mathrm{~mm}(1.20+0.11)$ (Table 1). Width of the head capsule for first, second and third generation was found to be ranged from $0.80-0.85 \mathrm{~mm}(0.83+0.02) ; 0.77-0.82$ $\mathrm{mm}(0.81+0.02)$ and $0.67-0.76 \mathrm{~mm}(0.75+$ 0.03 ) respectively (Table 2). However the developmental period first generations ranged from 5-7 days $(6.10 \pm 0.27)$, for second generation 2-4 days $(3.34 \pm 0.33)$ and for third generation varies from $3-5$ days $(4.00 \pm$ 0.29) (Table 3).

Observation on fourth (IV) larval instar revealed that this was the main damaging (cutting) instar and fed voraciously on the seedlings. The instar was darker than previous instar with typical mid-dorsal and supraspiracular lines. The length and width/ breadth of fourth instar varies from $7.9-8.7$ $\mathrm{mm}(8.41 \pm 0.10)$ and $1.5-2.2 \mathrm{~mm}$ respectively. Regarding head capsule measurements the larvae also shows significant variation among the three generations ranged from $1.30-1.40 \mathrm{~mm}$ $(1.37 \pm 0.03) ; 1.26-1.35 \mathrm{~mm}(1.34 \pm 0.02)$ and $1.10-1.42 \mathrm{~mm}(1.32 \pm 0.09)$ for first, second and third generation respectively (Table 2).

Fifth (V) instar larvae were grayish in colour with usual mid-dorsal and supra- spiracular lines. These were also feeding voraciously and cause more damage to seedlings. Cannibalism was also observed in fifth instar 
as when two larvae were kept with each other they started fighting resulted in eating up of weaker one by another. Matrices studies revealed that this instar possess length ranged between $14-20 \mathrm{~mm}(15.35 \pm 0.51)$ and the breadth of $2.3-3.5 \mathrm{~mm}(3.02 \pm 0.32)$. The head capsule width ranged from $2.20-2.50$ $\mathrm{mm}(2.45 \pm 0.09)$ for the first generation, 2.00 $-2.46 \mathrm{~mm}(2.34 \pm 0.12)$ for second generation and $1.90-2.42 \mathrm{~mm}(2.33 \pm 0.10)$ for third generation (Table 2). Similarly the duration for all the three generation ranges from 6-8 days ( $7.05 \pm 0.25)$; $4-6$ days $(5.15 \pm$ $0.33)$ and $5-7$ days $(6.33 \pm 0.22)$ (Table 3$)$.

Table.1 Morphometrics of different stages of A. ipsilon during 2019

\begin{tabular}{|l|l|l|l|l|}
\hline & \multicolumn{2}{|c|}{ Length/diameter(mm) } & \multicolumn{2}{c|}{ Breadth/width(mm) } \\
\hline \multicolumn{1}{|c|}{ Stages } & \multicolumn{1}{c|}{ Range } & \multicolumn{1}{c|}{ Mean \pm S.E } & \multicolumn{1}{c|}{ Range } & Mean \pm S.E \\
\hline Egg & $0.45-0.52$ & $0.48 \pm 0.04$ & - & - \\
\hline Larva & & & & \\
\hline I - instar & $1.8-2.3$ & $1.88 \pm 0.11$ & $0.35-0.52$ & $0.42 \pm 0.10$ \\
\hline II - instar & $3.1-4.6$ & $3.51 \pm 0.27$ & $0.60-0.83$ & $0.81 \pm 0.04$ \\
\hline III - instar & $5.5-7.2$ & $5.99 \pm 0.21$ & $0.91-1.3$ & $1.20 \pm 0.11$ \\
\hline IV - instar & $7.9-8.7$ & $8.41 \pm 0.10$ & $1.5-2.2$ & $2.01 \pm 0.16$ \\
\hline V - instar & $14.0-20.0$ & $15.35 \pm 0.51$ & $2.3-3.5$ & $3.02 \pm 0.32$ \\
\hline VI - instar & $30.00-36.66$ & $34.21 \pm 0.34$ & $3.5-4.8$ & $4.51 \pm 0.22$ \\
\hline
\end{tabular}

Table.2 Head capsule width (mm) of different larval instars of A. ipsilon during 2019

\begin{tabular}{|c|c|c|c|}
\hline \multicolumn{4}{|c|}{ First Generation } \\
\hline Larva & Range & Mean \pm S.E & Ratio \\
\hline I - instar & $0.30-0.34$ & $0.32 \pm 0.03$ & 1.56 \\
\hline II - instar & $0.45-0.52$ & $0.50 \pm 0.04$ & 1.66 \\
\hline III - instar & $0.80-0.85$ & $0.83 \pm 0.02$ & 1.65 \\
\hline IV - instar & $1.30-1.40$ & $1.37 \pm 0.03$ & 1.78 \\
\hline V-instar & $2.20-2.50$ & $2.45 \pm 0.09$ & 1.37 \\
\hline VI - instar & $3.00-3.40$ & $3.37 \pm 0.14$ & - \\
\hline \multicolumn{4}{|c|}{ Second Generation } \\
\hline Larva & Range & Mean \pm S.E & Ratio \\
\hline I - instar & $0.27-0.34$ & $0.31 \pm 0.05$ & 1.54 \\
\hline II - instar & $0.44-0.49$ & $0.48 \pm 0.03$ & 1.68 \\
\hline III - instar & $0.77-0.82$ & $0.81 \pm 0.02$ & 1.65 \\
\hline IV - instar & $1.26-1.35$ & $1.34 \pm 0.02$ & 1.74 \\
\hline V-instar & $2.00-2.46$ & $2.34 \pm 0.12$ & 1.43 \\
\hline VI - instar & $3.00-3.38$ & $3.36 \pm 0.12$ & - \\
\hline \multicolumn{4}{|c|}{ Third Generation } \\
\hline Larva & Range & Mean \pm S.E & Ratio \\
\hline I - instar & $0.30-0.36$ & $0.31 \pm 0.03$ & 1.48 \\
\hline II - instar & $0.42-0.47$ & $0.46 \pm 0.02$ & 1.63 \\
\hline III - instar & $0.67-0.76$ & $0.75 \pm 0.03$ & 1.76 \\
\hline IV - instar & $1.10-1.42$ & $1.32 \pm 0.09$ & 1.76 \\
\hline $\mathrm{V}$-instar & $1.90-2.42$ & $2.33 \pm 0.10$ & 1.40 \\
\hline VI - instar & $3.00-3.35$ & $3.28 \pm 0.06$ & - \\
\hline
\end{tabular}


Table.3 Duration of developmental stages in days of A. ipsilon during 2019

\begin{tabular}{|l|c|c|c|c|c|c|}
\hline \multicolumn{2}{|c}{ First Generation } & \multicolumn{2}{c|}{ Second Generation } & \multicolumn{2}{c|}{ Third Generation } \\
\hline Stages & Range & Mean $\pm \mathbf{S . E}$ & Range & Mean \pm S.E & Range & Mean \pm S.E \\
\hline Egg & $6.00-8.00$ & $7.00 \pm 0.25$ & $5.00-6.00$ & $5.40 \pm 0.22$ & $4.00-6.00$ & $5.20 \pm 0.28$ \\
\hline Larva & & & & & & \\
\hline I - instar & $6.00-8.00$ & $6.93 \pm 0.22$ & $4.00-6.00$ & $4.60 \pm 0.32$ & $5.00-7.00$ & $5.85 \pm 0.29$ \\
\hline II - instar & $5.00-7.00$ & $5.88 \pm 0.28$ & $3.00-4.00$ & $3.23 \pm 0.18$ & $3.00-5.00$ & $4.18 \pm 0.36$ \\
\hline III - instar & $5.00-7.00$ & $6.10 \pm 0.27$ & $2.00-4.00$ & $3.34 \pm 0.33$ & $3.00-5.00$ & $4.00 \pm 0.29$ \\
\hline IV - instar & $5.00-6.00$ & $5.43 \pm 0.17$ & $3.00-5.00$ & $4.03 \pm 0.33$ & $4.00-6.00$ & $4.88 \pm 0.38$ \\
\hline V - instar & $6.00-8.00$ & $7.05 \pm 0.25$ & $4.00-6.00$ & $5.15 \pm 0.33$ & $5.00-7.00$ & $6.33 \pm 0.22$ \\
\hline VI - instar & $10.00-13.00$ & $11.88 \pm 0.26$ & $8.00-11.00$ & $9.38 \pm 0.36$ & $8.00-11.00$ & $10.45 \pm 0.30$ \\
\hline Total & $\mathbf{4 1 . 5 0 - 4 4 . 7 5}$ & $\mathbf{4 3 . 2 5} \pm \mathbf{+ 0 . 1 7}$ & $\mathbf{2 7 . 2 5 - 3 3 . 0 0}$ & $\mathbf{2 9 . 7 1 + 0 . 3 2}$ & $\mathbf{3 2 . 0 0 - 3 7 . 0 0}$ & $\mathbf{3 5 . 6 8} \pm \mathbf{0 . 3 1}$ \\
\hline
\end{tabular}

Table.4 Mortality of larval stage of A. ipsilon during different generations at room temperature

\begin{tabular}{|l|c|c|c|c|c|c|}
\hline Generations & I-instar & II-instar & III-instar & IV-instar & V-instar & VI-instar \\
\hline I & 8.00 & 12.00 & 20.00 & 27.00 & 9.00 & 6.00 \\
\hline II & 10.00 & 15.00 & 23.00 & 43.00 & 13.00 & 8.00 \\
\hline III & 15.00 & 20.00 & 27.00 & 37.00 & 16.00 & 10.00 \\
\hline Mean & $\mathbf{1 1 . 0 0}$ & $\mathbf{1 5 . 6 7}$ & $\mathbf{2 3 . 3 3}$ & $\mathbf{3 5 . 6 7}$ & $\mathbf{1 2 . 6 7}$ & $\mathbf{8 . 0 0}$ \\
\hline
\end{tabular}

The sixth larval instar was the last instar observed during the whole life cycle. Its appearance was darker than other instars possessing high cannibalistic capacity. Morphologically, the mid dorsal longitudinal line and transverse bands in between segments appeared more prominent and it stops feeding 1 to 2 days before pupation. Body characteristics vary from $30-36 \mathrm{~mm}$ $(34.21+0.34)$ in length and $3.5-4.8 \mathrm{~mm}(4.51$ +0.22 ) in breadth. The width of head capsule ranged from $3.00-3.40 \mathrm{~mm}(3.37 \pm 0.14)$; $3.00-3.38 \mathrm{~mm}(3.36 \pm 0.12)$ and $3.00-3.35$ $\mathrm{mm}(3.28 \pm 0.06)$ for first, second and third generation respectively, and the instar lasted for 10 - 13 days $(11.88 \pm 0.26)$; 8 - 11 days $(9.38 \pm 0.36)$ and $8-11$ days $(10.45 \pm 0.30)$ days, during first, second and third generation respectively.

The larva shed its cuticle six times before the formation and therefore, there were six larval instars in each generation. The observation on ratio of head capsule width with the successive instars were 1.56, 1.66, 1.65, 1.78, and 1.37 for first generation; 1.54, 1.68, 1.65, 1.74 and 1.43 during second generation and $1.48,1.63,1.76,1.76$ and 1.40 for the third generation, this confirms to Dyar's law in determination of number of instar (Table 2).

\section{Larval mortality}

The per cent larval mortality during different larval instars in all the three generations ranged between 6- 37 per cent. The mortality percentage increased from first larval instar and attained a peak at fourth instar thereafter it decreases in fifth and sixth instar. During first generation the per cent mortality among first to sixth instars was found to be $8,12,20$, 27, 9 and 6 per cent respectively. Similarly for second generation larval mortality of 10 , $15,23,43,13$ and 8 per cent was recorded. While as for third generation the following trend was found from first to sixth instars 15, 
$20,27,37,16$, and 10 per cent respectively (Table 4).

The present findings are corroborated with the observations made by Nasr and Naguib (1964) and Alnaji and Ghafoor (1988) who too confirmed existence of six larval instars in each generation. Whereas, Archer and Musick (1977) and Troester (1982) opined that the cutworm larvae passes through seven instars. However, Luckmann et al., (1976) and Thippeswamy et al., (1981) found that larva had six instars with a portion of the population having the seventh instar. The author also recorded mean larval length as 2.1-19.50 $\mathrm{mm}$ from first to sixth larval instars are contradictory to the present observations. The variation might be probably due to the variation in agro-climatic regions and favorable abiotic factors required for growth and development. Though, Atwal (1986) reported that newly hatched caterpillar was $1.5 \mathrm{~mm}$ long and is in close conformity with present findings. Similarly, Vizi and Baghat (1998), revealed the mean larval length and breadth of $0.91-47.00 \mathrm{~mm}$ and $0.16-5.62 \mathrm{~mm}$ during different larval instars and are not in accordance with present investigations. However, the authors recorded the maximum mean per cent larval mortality in fourth instar as 28.00 per cent and minimum in newly hatched caterpillar which is in concurrence to current findings. According to Verma and Verma (2002) the mean length of larva from first to sixth instar was $3.03-44.3 \mathrm{~mm}$. Similarly, Pathnia (2010) also recorded an average larval breath in the successive instars as $0.44-4.7 \mathrm{~mm}$ and six imago stages during the course of study supports the present study. In union territory of Jammu and Kashmir, Bhat (1991) who opined the presence of six larval stages, also noticed the mean larval length between the range of $1.75-34.02 \mathrm{~mm}$ from first to sixth larval instar, with the mean larval duration as 7.13-13.53 days in first generation, 4.8-10.56 days in second generation and 5.86-11.2 days in third generation form first to sixth instar, respectively. Whereas, head capsule in the successive instar was in range as $0.3-3.2 \mathrm{~mm}$ are in concurrence with the study

\section{References}

Ainaji LK. and Ghafoor MS, M. M. 1988. Biological study of black cutworm Agrotis ipsilon (Huf.) (Lepidoptera: Noctuidae) reared on an artificial diet. ZANCO 1(1): 33-41.

Atwal A S. 1986. Agricultural Pests of India and South East Asia. Kalyani Publishers, Ludhiana. Total pages. 394.

Archer TL., Musick GL. and Murray R.L. 1980. Influence of temperature and moisture on black cutworm (Lepidopetra: Noctuidae) development and reproduction. Canadian Entomologist. 112 (7): 665-673.

Bhat AH. 1991. Biology and Management of Agrotis ipsilon (Hufnagel) in Kashmir, MSc. (Entomology) Thesis, Sherekashmir University of Agriculture Sciences and Technology, Srinagar, India (1991).

Gholson LE. and Showers WB. 1979. Feeding behaviour of black cutworms on seedling com and organic baits in the green house. Environmental Entomology, 8: 552-557.

Harcourt DG. 1969. The development and use of life tables in the study of natural insect populations. Annual Review of Entomology 14:175-196.

Johnson T B. and Lewis LC. 1982. Pathogenicity of two nuclear polyhedrosis viruses in the black cutworm, Agrotis ipsilon (Lepidoptera: Noctuidae). Canadian Entomologist, 114: 311- 316

Lone JI. and Zaki F.A. 1999. Management of black cutworm (Agrotis ipsilon Hufhagel) in maize (Zea mays L.) through cultural manipulations. 
SKUAST Journal of Research, 1: 64-70. Luckmann WH, Show JT, Sherrod DW. and Ruesink WG. 1976. Developmental rate of the black cutworm. Joumal of Economic Entomology 69(3): 386-388.

Nasr ESA. and Naguib MA. 1964. Contribution to the biology of the greasy cutworm, Agrotis ypsilon Rott. (Lepidoptera: Noctuidae). Bulletin de la Societe Entomologique d' Egypte 47: 197-200.

Odiyo PO.1975. Seasonal distribution and migrations of Agrotis ipsilon (Hufhagel) (Lepidoptera: Noctuidae). Central Overseas Pest Research Tropical Pest Bulletin, 4: 26

Pathania V. Distribution and biology of cutworms infesting potato in Himachal Pradesh. MSc. (Entomology) Thesis, CSK Himachal Predesh Krishi Vishvavidyalaya, Palampur, India, (2010), 69.

Rajendran TP. and Verma KD. 1989. Chemical control of cutworms Agrotis spp. (Noctuidae: Lepidoptera) on potato in the Nilgiris. Indian Joumal of Entomology. 51 (2): 177-180.

Renwick J A A. 1989. Chemical ecology of oviposition in phytophagous insects. Experientia, 45: 223-228.

Reshi ND. 1967. Studies on insect pests of Kashmir. Part vegetables. Major pests with their life history and control measures. Kashmir Science, TV (1-2): 66-69.
Showers W.B.1997. Migratory ecology of the black cutworm. Annual Review of Entomology 42: 393-425.

Showers WB, Kaster, LV. and Mulder PG. 1983. Com seedling growth stage and black cutworm (Lepidoptera: Noctuidae) damage. Environmental Entomology, 12: 241-244

Southwood TRE. 1978a. Ecological Methods with particular reference to the study of insect populations. Chapman and Hall, London. pp 524.

Thippeswamy C, Govindan R, Devaiah M. and Thimmaiah G. 1981. Studies on th bioecology of the greasy cutworm, Agrotis ipsilon (Hufhagel) (Lepidoptera: Noctuidae) on cotton. Mysore Joumal of Agricultural Sciences 15: 522-529.

Troester SJ.1982. Damage and yield reduction in field com due to black cutworm (Lepidoptera: Noctuidae) feeding; results of a computer simulation study. Journal of Economic Entomology 75: 1125-1131.

Verma KS and Verma AK. 2002. Biological studies on Agrotis ipsilon (Hufnagel) in Himachal Pradesh. Himachal Journal of Agricultural Research 28(1/2): 43-47.

Vizi CP. and Bhagat RM. (1998). Study on life history of black cutworm, Agrotis ipsilon Hufn. on maize. Shashpa 8(1): 33-39.

\section{How to cite this article:}

Aoufa Mushtaq, Z. H. Khan, S. S. Pathania, Sajjad Hussain Mir, Khalid Rasool, Showkat Maqbool and Raihana Habib Kant. 2021. Larval Biology of Black Cutworm Agrotis ipsilon on Maize in Kashmir. Int.J.Curr.Microbiol.App.Sci. 10(02): 3382-3388.

doi: https://doi.org/10.20546/ijcmas.2021.1002.372 